\title{
ヘマトキシリン染色絹布の表面色に及ぼす空気酸化の影響
}

\author{
京都女子大学短期大学部 坂田 佳子
}

\section{The Effects of Air Oxidation on the Surface Color of Silk Fabrics Dyed with Hematoxylin}

\section{Keiko Sakata}

\author{
Kyoto-Women's College, 35, Kita-hiyoshi Cho, Imakumano Higashiyama-ku, 605-8501, Japan
}

\begin{abstract}
In order to clarify whether the colorless hematoxylin absorbed in the silk fiber is oxidized to hematein by oxygen in air, the time-course of $\mathrm{K} / \mathrm{S}-\lambda$ curve of the silk fabric dyed at the different $\mathrm{pH}$ with hematoxylin was investigated by keeping them at ambient temperature and humidity for 40 days. Either of the silk fabrics dyed at pH3.9 and 4.9 were colorless and, if these fabrics were exposed by air for 40days, colored to brownish yellow, implying that hematoxylin inside the fiber was oxidized to hematein. In addition, it was found that a portion of hematein absorbed in silk fabrics dyed at over pH5.9 was faded by oxygen in air. Consequently, the color yield of fabrics during storage was considered to result from a balance of the oxidation of hematoxylin and the discoloration of hematein.
\end{abstract}

(Received 25 October, 2008 ; Accepted 5 January, 2009)

\section{1. 緒 言}

先の研究報告では, ヘマテイン $\left[\mathrm{C}_{16} \mathrm{H}_{12} \mathrm{O}_{6}\right]$ (以降 $\mathrm{Hem}$ )の 前駆物質である無色のヘマトキシリン $\left[\mathrm{C}_{16} \mathrm{H}_{14} \mathrm{O}_{6}\right]$ (以降 $\mathrm{Htx}$ )を用い絹布に対する染着挙動について考察を行った そして, Htx 染色絹布の表面色は染浴温度, 時間とともに 染浴 $\mathrm{pH}$ により大く影響を受けること，また，表面色は 染浴中で酸化した Hem の絶対量が大きく寄与しているこ となどを明らかした[1]。この報告の中で検討した Htx 染 色布の表面色は, 酸化後の Hem の表面染料濃度を表して いる. 従って, 染色直後に無色の Htx は, 染色前後の吸 収スペクトルの吸光度 $(289 \mathrm{~nm})$ の差から若干吸着は認めら れたが，無色であるため瀻維への着色は認められず，染 色直後は, 瀻維内に吸着した Htx は Hem に酸化されてい ないことを示している.

これまでに, 我々は羊毛瀻維の酸化染料染色に打いて, 酸化重合反応により生成する無色のロイコ染料が繊維に 吸着し, 染色後 数十日かけて空気酸化により発色するこ とを報告した[2].この結果から推測すると, 瀻維内に吸 着した Htx も酸化染料のロイコ体と同様に空気酸化によ り Hemに変換されると考えられる，そこで，Htx は瀻維 に吸着後, Htx のまま存在しつづけるのか, それとも空気 中の酸素により酸化され Hem となりうるのかを明らかに することを目的として, 染浴 $\mathrm{pH}$ を変えた Htx 染色絹布の 表面色が空気酸化によりどのように変化するかを, 染色 直後からその後 40 日間にわたり経日追跡を行った，そし て, 各染浴に扔ける染色直後の絹布上の色素成分を検討 し Htx の吸着の有無を確認した.

\section{2. 実 験}

\section{1 試料}

染色に用いた絹布は, 前報告と同様の市販の染色試験 用絹羽二重(密度: タテ 135 本/インチ, ヨコ 98 本/インチ, 目 付け $55.13 \mathrm{~g} / \mathrm{m}^{2}$, (株色染社)をそのまま染色に供した.

\section{2 試薬}

染色に用いたへマトキシリン(東京化成製) は試薬特級 を使用した。色素溶解剤には2-メトキシエタノールを, ミ カエリス $\mathrm{pH}$ 緩衝液の調整にはジエチルバルビッール酸ナ トリウムを用い,その他, 実験に用いた試薬はいずれも市販 試薬 1 級あるいは特級を使用した。

\section{3 染色方法}

染色用の色素溶液は, 試薬 Htx $0.06 \mathrm{~g}$ を2-メトキシエタ ノール $0.25 \mathrm{ml}$ を加えて溶解後, ミカエリス緩衝液を所定 液量の約 $1 / 4$ の $60 \mathrm{ml}$ を加え $\mathrm{pH} 3.9,4.9,5.9,6.8,7.9$ の $\mathrm{Htx}$ 染料溶液 $250 \mathrm{ml}$ (色素濃度 : $\left.8 \times 10^{-4} \mathrm{~mol} / 1\right)$ を各々染色直前に

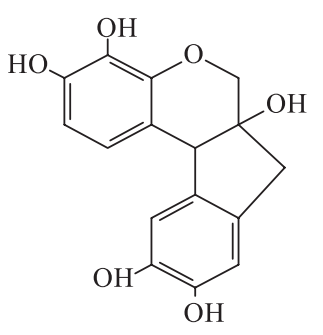

$1 \mathrm{a}$

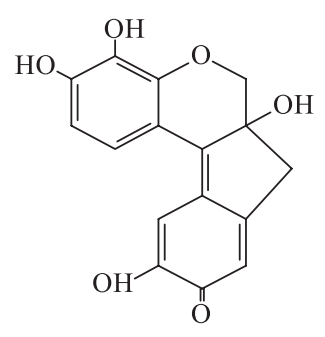

$1 b$
Fig. 1 Structural fomulas of hematoxylin (1a) and hematein (1b). 
調整した. 各染料溶液 $83 \mathrm{ml}$ と試料の絹布 $1 \mathrm{~g}$ を共栓付褐 色三角フラスコに入れ，蓋を閉めて $40^{\circ} \mathrm{C}$ の恒温槽で $2 \mathrm{hr}$ 振とうした. 染色終了後は絹布を取り出し蒸留水 $100 \mathrm{ml}$ で 2 回水洗後, ろ紙に挟み自然乾燥させた。

\section{4 染色布の表面染料濃度の測定}

染色絹布の表面反射率を同時測光方式分光測色計 ( 株) 日本電色,SQ-2000)を使用し, 染色直後から40日まで染 色布の表面反射率の測定を行ったここの值を基に KubelkaMunk 関数を用いて極大吸収波長の表面染料濃度 $(\mathrm{K} / \mathrm{S}$ 值) を求めた. また, 経過測定の染色絹布は直射日光を遮断 し室温内で保管した。

\section{3. 結果と考察}

\section{1 染色絹布表面色の染色直後と 40 日経過後の K/ $S$ 值- $\lambda$ 曲線}

図 2(A) に染浴 $\mathrm{pH} 3.9$ ～7.9 における絹布 2 時間染色直後 の $\mathrm{K} / \mathrm{S}$ 值- $\lambda$ 曲線を, 図 $2(\mathrm{~B})$ に同じく 40 日経過後のそれ を示す.まず, 染色直後の曲線をみると, 最も低い pH3.9 は吸収のピークはほとんど認められず目視では無色に近 い. pH4.9でわずかに $460 \mathrm{~nm}$ 付近に吸収が現れるが,最大 吸収波長の K/S 值は低く淡黄色を示す. pH5.9になると ピーク $(460 \mathrm{~nm})$ は大幅に増大すると同時に,長波長側 (530$580 \mathrm{~nm})$ に若干の膨らみが認められる。 pH6.8では主ピー ク $(460 \mathrm{~nm})$ はさらに増大し,波形もよりシャープになって 長波長側の膨らみも増加した.しかし, pH7.9では主ピー ク $(460 \mathrm{~nm})$ は大きく減少してブロードに変化し,長波長側

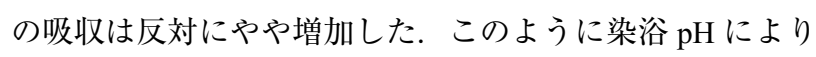
分光カーブの波形が異なるのは,先の報告 [1]に述べたよう に Hem 色素の水酸基(-OH)の解離状態が影響したもので ある. 続いて, 染色直後と同染色絹布の 40 日後の図 2 (B) と比較を行う。まず, pH3.9 は大きく増加を示すと同時に, 短波長側 (380-400nm) の吸収も増えるため明らかなピーク は認められない. pH4.9では短波長側の増加に伴い全波長 にわたり増加を示すが, 吸収のピーク波長は染色直後とほ

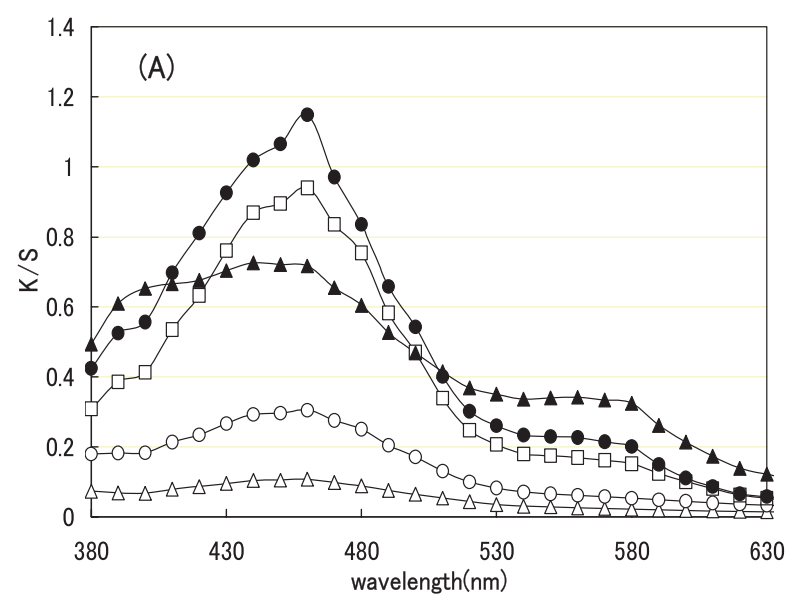

ぼ同じである.しかし, pH5.9になるとピーク波長 $(460 \mathrm{~nm})$ は変わらないがその $\mathrm{K} / \mathrm{S}$ 值は直後に比べ約 3 割減少して いる. 続く pH6.8ではピーク波長の K/S 值の減少と同時 に染色直後の吸収波形のシャープさは消えブロードな波 形になった.さらに $\mathrm{pH} 7.9$ では染色直後に認められた 460 $\mathrm{nm}$ および $580 \mathrm{~nm}$ 付近に極大吸収をもつ2つのピークは 40 日後共に消失した.

このように染色直後と 40 日経過後の曲線を比較すると, 染浴の $\mathrm{pH}$ により $\mathrm{K} / \mathrm{S}$ 值が増加している染料と減少する染 料が存在することが明らかとなった. しかし, 各々の染 料で K/S 值は変化するものの曲線の形やピーク変化は大 きく認められなかった。 従って, 染色布の表面色に及ぼ す空気酸化の影響について, 染色直後から40日経過後ま での各 K/S 值- $\lambda$ 曲線の最大吸収波長 $(460 \mathrm{~nm})$ の K/S 值の 変化に主眼をおき検討した。

\section{2 染色絹布の表面染料濃度に及ぼす空気酸化の影} 響

図 3 に Htx 染色 2 時間の染色直後より 40 日までの表面 色の最大吸収波長 $(460 \mathrm{~nm})$ の K/S 值の経日変化を示した. 変化の特徵は図からも明らかなように, pH3.9 と pH4.9 は 緩やかな増加を示し, pH5.9 と 6.8 では急激な低下の後, わずかに増加し, その後再び低下する曲線を描いた. pH7.9 の K/S 值は 40 日後の低下が最も大きく, 数日後で著しく 低下し, その後はわずかに減少する曲線となった。この ような絹布の表面色の経日変化は, Htx 染色時の染浴 $\mathrm{pH}$ の条件により, 染色直後の絹布上に吸着している色素構 造が異なることを示唆している. すなわち, 低い $\mathrm{pH}$ 範囲 の最大吸収波長 $(460 \mathrm{~nm})$ の $\mathrm{K} / \mathrm{S}$ 值の増加は, 空気酸化によ り纎維上で Htx に酸化反応が起こっていることを示し, 染色直後の絹布上には還元型 Htx の存在が考えられる. それに対して, 染浴 $\mathrm{pH}$ が高くなると K/S 值は次第に減少 し退色が起こるのは, Hem の酸化が進行していることを 表している.

以上の結果を受けて, 各染浴 $\mathrm{pH}$ における吸着色素を推 定した. まず, $\mathrm{pH} 3.9$ のように徐々に K/S 值が増加を示す

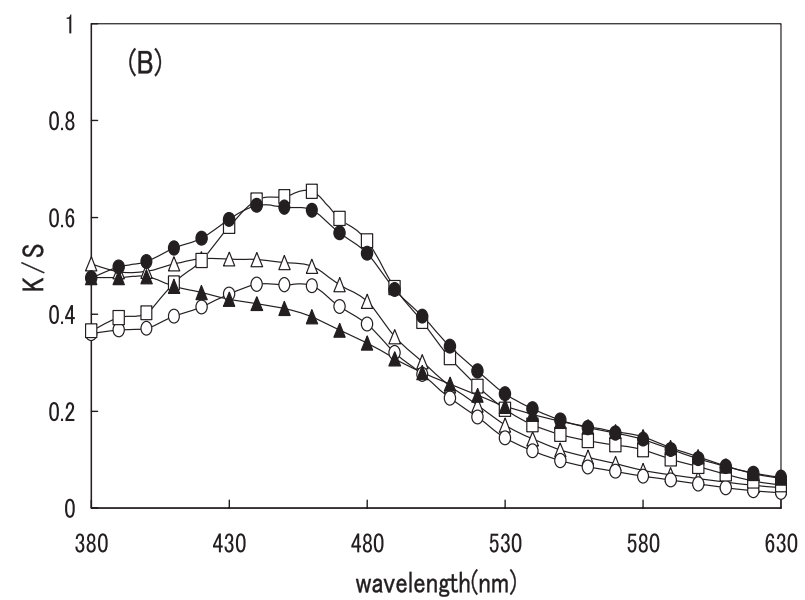

Fig. 2 Plots of K/S Versus wavelength for the silk fabrics dyed at $40^{\circ} \mathrm{C}$ for $120 \mathrm{~min}$ dyeing, (A) : immediately after dyeing, (B) : storage 40days after dyeing, pH3.9( $\triangle)$, pH4.9 $\bigcirc), \mathrm{pH} 5.9(\square), \mathrm{pH} 6.8(\bigcirc), \mathrm{pH} 7.9(\boldsymbol{\Delta})$. 


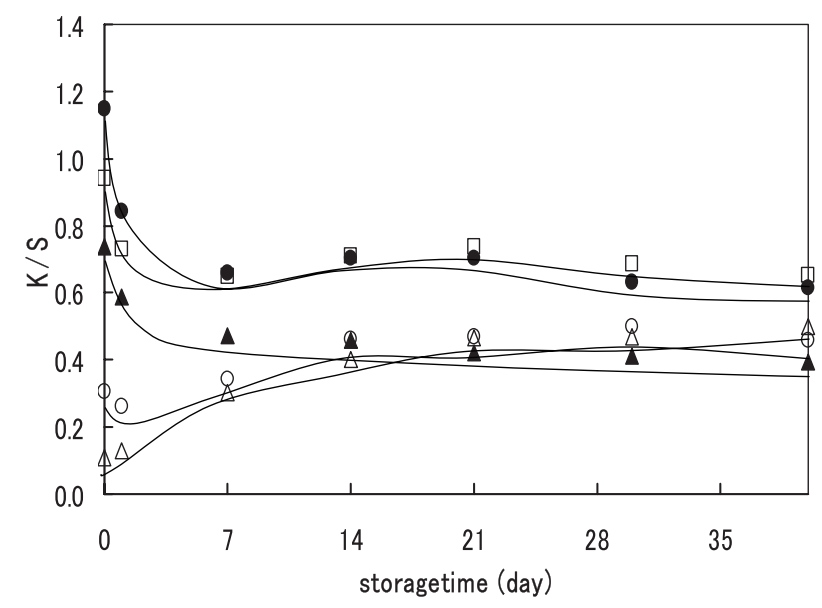

Fig. 3 Plots of K/S Versus Storage time(day) for dyed silk fabrics, dyeing condition : $\mathrm{pH} 3.9(\triangle), \mathrm{pH} 4.9$ (○), pH5.9( $\square)$, pH6.8(○), pH7.9(스), dyeing time $120 \mathrm{~min}, 40^{\circ} \mathrm{C}$

場合は, 染色直後の絹布上には Htx の存在が明らかでこ の $\mathrm{pH}$ 域ではほとんどが Htx の吸着である. 続く $\mathrm{pH} 4.9$ の 染色直後の K/S 值は, $\mathrm{pH} 3.9$ に比べると高いが, 40 日経 過後の K/S 值の増加率は $\mathrm{pH} 3.9$ に比べ大きく抑えられた。

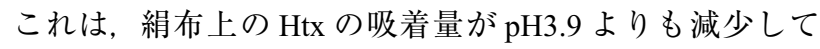
いることを示している. また, 染色 1 日後のわずかな K/S 值の減少から, 酸化生成した Hem の吸着も若干認められ るが, この $\mathrm{pH}$ 域でも Htx の吸着が大部分を占めていると 考えられる. 一方, pH 5.9 と 6.8 の K/S 值は翌日から急激 な減少を示し, その原因として, 繊維上の Hem の空気酸 化が進み色素分解が始まったことが推測できる，因みに このような急激な減少は, Htxよりも Hem の方が空気酸 化に対し不安定であることからも明らかである．従って， この $\mathrm{pH}$ 域では，染浴中には Htx よりも酸化型 Hem の絶 対量が増大するため, 繊維上には Hem の吸着が増加して いる.また，この $\mathrm{pH}$ 域において，K/S 值は一旦低下する ものの 21 日後に若干の増加が認められるのは, Htx 存在 の裏付けとなっている. さらに, pH7.9の K/S 值は翌日か
ら減少を示し, 7 日目以降の曲線からは $\mathrm{K} / \mathrm{S}$ 值の増加は見 てとれなかった.これは $\mathrm{pH} 6.8$ に比べ染色直後の $\mathrm{K} / \mathrm{S}$ 值 がほぼ $1 / 2$ と低いことからもわかるように, 染浴中の Hem 絶対量の減少によるものであり, 退色変化は図 $2(\mathrm{~B})$ の $\mathrm{pH}$ 7.9 の分光カーブの 2 つのピークが消失したことからも明 らかに見てとれる.

\section{4. 結 論}

本実験により, Htx 染色絹布の表面染料濃度は経日の空 気暴露により変化が認められた。 それは染色時の染浴 $\mathrm{pH}$ により異なり, 低い $\mathrm{pH}$ 領域においては色目が徐々に深く なるのに対して, $\mathrm{pH}$ が高くなると反対に退色し, その原 因として, 繊維上の吸着色素の割合が密接に関係してい ることがわかった.すなわち, 染色直後の Htx の量が多 いときは, 徐々に空気酸化により Hem への酸化生成が進 行し表面染料濃度 K/S 值は高くなるが, Hem 量が多いと きは, その量の増加に伴い, 次第に Hem の酸化分解が進 むため表面染料濃度は低下を示すことが明らかになった。

以上の結果から, 染浴 $\mathrm{pH}$ により Htx の染浴中の濃度は 異なるが, それに応じて Htx が絹布に吸着していること が確認できた.

\section{謝 辞}

おわりに，本研究にご協力いただきました京都女子大 学家政学部 平成 19 年度卒業生の赤岡香里, 高橋絵理の両 氏に謝意を表します。

\section{文 献}

1. K.Sakata, Sen'i Gakkaishi,, 64, 229-235 (2008).

2. Y.Yoshikatsu, K.Sakata and K.Joko, Sen'i Gakkaishi,, 62, (2007). 